\title{
Sea
}

JURNAL PENDIDIKAN GEOGRAFI

\section{PENERAPAN MODEL PEMBELAJARAN BERBASIS PROYEK UNTUK MENGEMBANGKAN KEPEDULIAN PESERTA DIDIK TERHADAP LINGKUNGAN}

\author{
Catur Nurrochman Oktavian'1, Enok Maryani2 \\ Program Studi Pendidikan IPS, SPs, UPI, \\ email: catur.oktavian@yahoo.co.id
}

\begin{abstract}
The research was prompted by students' lack of environmental awareness. Cultivating concern and responsibility for environmental awareness can be carried out through social studies teaching and learning. In general, the research aimed to see differences in the effectiveness of project-based learning model in social studies teaching and learning in the experimental class and the use of problem-based learning model in the control class to develop students' environmental awareness. It employed quantitative approach with quasi-experimental method. The design used was Non-Equivalent PretestPosttest Control Group Design. The population of this research included all seventh graders of SMP Negeri 1 Kemang, Bogor Regency. Students' environmental awareness appeared to improve after teaching and learning, as can be observed from their discipline in putting trash to its place, communal work to clean up scribbles on the desk and classroom walls, and active participation in keeping the classroom clean. The research results also show positive responses from students because project-based learning gives project assignments that provided them with opportunities to develop their confidence and hone their creativity. Students' activity in teaching and learning increased, as observed from their active involvement and independence in completing the projects during the teaching and learning process. Teachers responded positively and viewed that social studies teaching and learning process implementing project-based model had more advantages, namely: It could improve teachers' knowledge and understanding of the syntax of innovative learning models and improve their abilities and skills in managing, organizing, and conducting instruction in the classroom. The obstacles encountered in the implementation of this project-based learning model were time allocation and the long preparation for teachers in order for the model to work well.
\end{abstract}

Keywords: project based learning model, environmental awareness, social studies.

\section{PENDAHULUAN}

Pendidikan yang berkualitas tidak hanya berorientasi kepada capaian-capaian aspek kognitif saja, melainkan berfokus juga kepada pengembangan aspek sikap dan nilai, serta aspek keterampilan. Pendidikan sebagai bentuk perwujudan kebudayaan manusia harus mampu menggerakkan dan mendukung pembangunan di masa depan. Pendidikan harus mampu mengembangkan potensi peserta didik secara komprehensif, sehingga mampu menghadapi dan memecahkan permasalahan kehidupan yang semakin kompleks.

Pendidikan sebagai upaya meningkatkan kualitas sumber daya manusia harus berfungsi untuk menghasilkan para lulusan sesuai kompetensi yang diharapkan, sebagaimana amanat UU RI No. 20 tahun 2003 tentang Sistem Pendidikan Nasional, Bab II Pasal 3 mengenai Dasar, Fungsi dan Tujuan Pendidikan Nasional, bahwa:

Pendidikan nasional berfungsi mengembangkan kemampuan dan membentuk watak serta peradaban bangsa yang bermartabat dalam rangka mencerdaskan kehidupan bangsa, bertujuan untuk berkembangnya potensi peserta didik agar menjadi manusia yang beriman dan bertakwa kepada Tuhan Yang Maha Esa, berakhlak mulia, sehat, berilmu, cakap, kreatif, mandiri, dan menjadi warga 
negara yang demokratis serta bertanggung jawab.

Mencermati rumusan tujuan pendidikan nasional tersebut, terdapat keinginan besar dari bangsa ini agar kegiatan pendidikan melahirkan insan-insan yang memiliki keseimbangan antara kehidupan jasmani dan rohaninya, sebagai gambaran manusia Indonesia seutuhnya.

Berdasarkan tujuan pendidikan nasional yang telah dikemukakan sebelumnya, dapat dimaknai bahwa pada hakekatnya pendidikan adalah sebagai upaya dari manusia untuk menghasilkan insan-insan yang berkualitas agar mampu menghadapi dan memecahkan persoalanpersoalan yang dihadapi dalam kehidupannya. Persoalan-persoalan kehidupan manusia dilihat dari konteks sosial kian hari bertambah banyak, dan semakin kompleks. Bahkan akhir-akhir ini dengan semakin bertambahnya jumlah penduduk di dunia dan semakin terbatasnya sumbersumber penghidupan manusia, membuat kehidupan manusia semakin kompleks, kompetitif, dan menjadi tidak menentu. Hal ini terjadi bukan hanya karena keterbatasan manusia secara fisik yang disebabkan jumlah dan kepadatan penduduk, tetapi juga persaingan hidup secara sosial semakin sulit.

Manusia sebagai mahluk sosial, baik secara individu maupun kelompok tidak lepas dari interaksi dengan lingkungannya, baik sesama manusia maupun lingkungan alamnya. Corak hubungan antara manusia dengan lingkungannya mengalami perubahan sesuai dengan perkembangan zaman dan kemajuan peradaban manusia. Perubahan dan perkembangan ini juga yang membuat manusia dihadapkan pada berbagai persoalan dalam kehidupannya. Salah satu persoalan dalam kehidupan manusia adalah permasalahan tentang lingkungan. Manusia amat berperan penting dalam persoalan yang muncul akibat nteraksinya dengan lingkungan, karena manusia sebagai pelaku maupun penderita dikarenakan permasalahan yang timbul dari kerusakan lingkungan. Hal ini dimaksudkan agar dalam menanggulangi permasalahan lingkungan berhubungan erat dengan penanganan sikap dan perilaku manusia sebagai ujung pangkalnya.

Menurut para ahli pendidikan lingkungan, kebanyakan orang tidak menggunakan kesadaran lingkungan mereka untuk berperilaku peduli terhadap lingkungan. Untuk menumbuhkan kesadaran siswa dalam bersikap dan berperilaku yang peduli terhadap lingkungannya, maka peran pendidikan lingkungan amatlah penting. Pendidikan lingkungan merupakan proses yang ditumbuhkan sepanjang hayat dan sekolah memiliki peran mengambil salah satu bagian dari proses tersebut yang diterapkan melalui pendekatan interdisipliner dan holistik. Hal ini sebagaimana kesepakatan umum yang dituang dalam Tbilisi Report Recommendation (Palmer \& Neal, 1994) dimana beberapa butir kesepatan diantaranya bahwa pendidikan lingkungan adalah proses sepanjang hayat, interdisiplin dan holistik dalam penerapannya, pendekatan pendidikan dibandingkan materi, perhatian terhadap keterkaitan dan keterhubungan antara manusia dan sistem alam, mendorong partisipasi dalam pembelajaran.

Peningkatan pengetahuan dan pembinaan sikap serta perilaku terhadap kepedulian lingkungan harus ditumbuhkan sejak dini dalam pendidikan lingkungan yang dapat diterapkan melalui kegiatankegiatan pembelajaran nyata yang terkait dengan kehidupan sehari-hari. Penanaman karakter kepedulian lingkungan menekankan bagaimana agar siswa selaku peserta didik memiliki moral dan etika yang terinternalisasi dalam sikap dan perilakunya, baik di sekolah maupun di lingkungan lainnya. Pembentukan budaya dan karakter berupa kepedulian terhadap lingkungan menjadi perhatian pula dalam pendidikan di Indonesia sebagaimana dikemukakan oleh Pusat Kurikulum (2010, hlm. 10):

Kepedulian lingkungan di Indonesia merupakan salah satu nilai yang 
dikembangkan dalam pendidikan budaya dan karakter bangsa. Kepedulian lingkungan dideskripsikan oleh sikap dan tindakan yang selalu berupaya mencegah kerusakan pada lingkungan alam di sekitarnya, dan mengembangkan upaya-upaya untuk memperbaiki kerusakan alam yang sudah terjadi.

Menanamkan kesadaran dan tanggung jawab akan kepedulian lingkungan tidak hanya dalam bentuk pendidikan lingkungan yang berdiri sendiri secara tunggal dan parsial melainkan dapat diintegrasikan ke dalam berbagai mata pelajaran dan salah satunya adalah dalam mata pelajaran Ilmu Pengetahuan Sosial (IPS). Mata pelajaran IPS merupakan salah satu bagian dari kurikulum sekolah yang materinya diturunkan dari isi materi cabang-cabang ilmu sosial yang mempelajari gejala-gejala kehidupan yang cukup luas, karena mencakup masalah-masalah kehidupan manusia di masyarakat dan interaksi dengan lingkungannya.

Dalam sepuluh tema social studies atau IPS (ten thematic strands in social studies) yang dirumuskan secara formal oleh National Council for the Social Studies (NCSS, 1993, hlm.23) salah satunya adalah Manusia, Tempat, dan Lingkungan (People, Places, and Environtment). Berdasarkan salah satu tema pokok IPS tersebut peserta didik dapat terbantu mengembangkan pandangan spasial dan perspektif geografi di lingkungannya. Manusia dalam kehidupan sebagai mahluk sosial baik secara individu maupun kelompok tidak bisa lepas dari interaksi dengan lingkungannya, baik sesama manusia maupun lingkungan alamnya. Hubungan antara manusia dan lingkungannya merupakan aspek yang ditelaah dalam pendidikan mengenai lingkungan. Pendidikan lingkungan yang diterapkan dalam mata pelajaran sekolah termasuk dalam Ilmu Pengetahuan Sosial (IPS) bertujuan untuk membangun dan mengembangkan kompetensi peserta didik melalui transfer pengetahuan, sikap dan keterampilan sehingga diharapkan peserta didik memiliki kemampuan (skill) dalam bersikap dan bersahabat terhadap lingkungan.

Secara faktual, sebagian besar guru kurang menyadari dan memahami muatan lingkungan dalam pembelajaran IPS merupakan salah satu bagian dari sepuluh tema pokok social studies berdasarkan acuan dari NCSS seperti telah tersebut di atas. IPS yang membahas manusia dan interaksinya terhadap lingkungan juga menjadi salah satu tema bahasan mata pelajaran IPS seperti yang termuat dalam kurikulum 2013. Tema ini menjadi salah satu bagian penting dalam konteks pengembangan ilmu pengetahuan yang berwawasan ekologis dengan membekali peserta didik pengetahuan, sikap dan nilai, serta keterampilan yang sesuai dengan prinsipprinsip ekologis.

Pendidikan lingkungan yang terintegrasi dalam pembelajaran di sekolah tidak begitu nampak dijumpai hasilnya di kehidupan nyata baik yang terlihat di lingkungan sekolah maupun di lingkungan masyarakat. Indikasi ini nampak dari berbagai permasalahan lingkungan yang berakar dari sikap dan perilaku siswa dalam kehidupan sehari-hari yang tidak menghargai dan kurang peduli terhadap lingkungan sekitar. Hal tersebut dapat disebabkan bahwa penerapan pendidikan lingkungan masih belum aplikatif dalam penyelesaian permasalahan lingkungan yang terjadi, sebagaimana dikemukakan oleh Kementerian Lingkungan Hidup Indonesia (2004) yang menyatakan bahwa materi dan metode pelaksanaan pendidikan lingkungan hidup tidak aplikatif, kurang mendukung penyelesaian permasalahan lingkungan hidup yang dihadapi di daerah masing-masing.

Terkait dengan pendidikan nilai, sekolah sebagai wahana berlangsungnya pendidikan nilai namun kenyataannya belum mampu mewujudkan perilaku peserta didik sesuai nilai-nilai yang diharapkan sebagai hasil dari suatu pendidikan. Indikasinya dapat terlihat 
dalam berbagai hal diantaranya adalah perilaku membuang sampah sembarangan yang mengakibatkan lingkungan kotor, partisipasi siswa yang masih rendah dalam kegiatan-kegiatan menjaga lingkungan, belum terbentuknya kesadaran menjaga dan melestarikan lingkungan sekitar.

Salah satu bentuk pendidikan nilai untuk menanamkan karakter moral pada diri siswa terdapat dalam pendidikan tentang lingkungan yang dapat terintegrasi dalam berbagai mata pelajaran termasuk mata pelajaran IPS. Pada pendidikan tentang lingkungan terdapat penanaman nilai sebagai pembentukan karakter pada diri siswa yang seiring sejalan dengan tujuan pendidikan nasional. Untuk menanamkan karakter dalam diri peserta didik melalui pendidikan lingkungan masih ditemui berbagai kelemahan diantaranya pendidikan di lingkungan yang diberikan kepada peserta didik lebih dominan pada muatan pengetahuan yang tidak aplikatif sehingga peserta didik tidak dapat membangun dan memahami makna yang mendalam dari hakikat menjaga peduli, dan melestarikan lingkungan. Pendidikan lingkungan tidak dikaitkan dengan permasalahan riil dan memuat halhal yang praktis dari kehidupan nyata di sekitar peserta didik. Kelemahankelemahan yang muncul dalam pendidikan untuk menanamkan karakter di pendidikan lingkungan tidak terlepas dari lemahnya proses pembelajaran yang terjadi di dalam kelas. Hal ini mengakibatkan penanaman nilai untuk membentuk karakter peserta didik melalui materi pelajaran bermuatan lingkungan yang sejalan dengan tujuan pendidikan nasional belum optimal.

Untuk mendukung tercapainya pelaksanaan pendidikan lingkungan selaras dengan tujuan pendidikan nasional dan memperhatikan pula perkembangan global saat ini, menuntut dunia pendidikan terutama dalam pelaksanaan proses pembelajaran selalu mengubah konsep berpikirnya. Menurut Suyono \& Hariyanto (2012, hlm 4) “masa depan yang kian tidak menentu dengan berbagai tantangan melekatnya yang dihadapi oleh umat manusia pada abad ke-21 memiliki implikasi luas dan mendalam terhadap berbagai macam rangsangan pengajaran dan teknik pembelajaran". Hal tersebut terkait dengan tugas dan kewajiban moral guru untuk mendorong dan memotivasi peserta didik agar belajar pengetahuan serta keterampilan yang diperlukan dan untuk memacunya agar lebih kreatif, inovatif, fleksibel, dan adaptif dalam menjalani kehidupannya sehari-hari. Guru berperan sangat strategis dalam melaksanakan proses pembelajaran di kelas yang membawa konsekuensi bagi guru untuk semakin menyadari bahwa model, metode, dan strategi pembelajaran yang umumnya dilakukan secara konvensional tidak akan cukup membantu peserta didik. Untuk menjadikan peserta didik kreatif, inovatif, dan adaptif, maka guru dituntut untuk inovatif, kreatif, dan adaptif serta mampu membawa suasana pembelajaran yang menyenangkan di dalam kelas, di mana terjadi interaksi belajar mengajar yang efektif dan multiarah. Dalam pembelajaran yang multiarah, guru mengajar sekaligus belajar, peserta didik belajar sekaligus menjadi pengajar bagi temannya.

Dalam belajar terdapat proses kegiatan mental peserta didik yang dilakukan secara sadar agar memiliki bekal produktif dan kreatif dalam memenuhi dan mempertahankan kehidupannya. Uno (2009, hlm. 54) yaitu: "Dalam mempertahankan kehidupannya, manusia harus mempunyai bekal kecakapan hidup (skill of life), yang dapat diperoleh melalui berbagai proses belajar, seperti belajar untuk mengetahui (learning to know), belajar untuk melakukan (learning to do), belajar untuk menjadi diri sendiri (learning to be myself), dan belajar untuk hidup bersama (learning to life together).

Keempat jenis belajar tersebut harus dilakukan manusia, jika ingin tetap survive dalam kehidupannya. Dalam prakteknya 
bahwa pembelajaran sebagai suatu proses pendidikan masih ditemui berbagai kelemahan-kelemahan baik dari faktor guru maupun peserta didik. Adanya kelemahan tersebut dikarenakan guru menguasai proses pembelajarannya dengan menggunakan metode yang monoton, yaitu hanya mengandalkan metode ceramah dalam pelaksanaannya. Seperti yang dikemukakan oleh Somantri (2001, hlm 39) "pendekatan ekspositori sangat menguasai keseluruhan proses belajar mengajar". Apabila pembelajaran di sekolah masih berorientasi ceramah, dan siswa hanya dijadikan objek maka akan banyak siswa yang menganggap belajar adalah aktivitas tidak menyenangkan, dan membosankan.

Jika guru dalam mengajar hanya menggunakan metode yang monoton maka tujuan pembelajaran sebagai upaya mengubah sikap dan perilaku siswa tidak tercapai. Menurut Maftuh dan Makah A.K. (2007, hlm 30), “Mengajar adalah suatu proses perubahan perilaku, oleh karena itu pengajar harus : a). Menciptakan berbagai kesempatan kepada siswa untuk menerima dan mengenali informasi baru. b). Berupaya membimbing siswa ke arah perolehan perilaku baru (yaitu bagaimana cara belajar, melaksana-kan, dan belajar merasakan".

Tujuan pembelajaran merupakan rumusan perilaku untuk menghasilkan perubahan pada diri siswa, sebagai akibat kegiatan mengajar dan belajar, yang mencakup kognitif (pengetahuan), afektif (sikap), dan psikomotor (keterampilan), baik yang merupakan efek bersifat langsung (instructional effects) maupun tidak langsung atau bawaan (nurturant effects). Dalam pembelajaran IPS tidak terlepas dari berbagai kelemahankelemahan pembelajaran yang dilakukan guru. Berdasarkan hasil pengamatan dan pengalaman yang dilakukan, teknik ceramah adalah yang paling mudah dan umumnya dilakukan oleh guru sejak dulu. Namun untuk masa mendatang teknik ini sebaiknya tidak terlalu banyak digunakan.
Adanya kelemahan-kelemahan dalam pembelajaran IPS dikemukakan pula oleh Maryani (2008, hlm 3) sebagai berikut : (1) adanya anggapan IPS merupakan "second class" tidak memerlukan kemampuan yang tinggi dan cenderung santai dalam belajar. (2) IPS sering kali dianggap jurusan yang sulit mendapat jaminan masa depan dan sulit mendapat pekerjaan yang lebih prestisius di masyarakat (3) Pembelajaran IPS sarat dengan hafalan sejumlah materi (4) Melemahnya nasionalisme, banyaknya penyimpangan sosial saat ini seperti tawuran, korupsi, hedonisme, disintegrasi bangsa, ketidakramahan terhadap lingkungan.

Terdapatnya kelemahan pembelajaran IPS seperti tersebut di atas, tidak terlepas dari kurangnya penggunaan sumber daya dan model pembelajaran lain yang inovatif oleh guru dalam melaksanakan proses pembelajaran. Kurangnya guru dalam menggunakan model pembelajaran yang inovatif dan strategi yang bervariasi dalam proses pembelajaran, akan berdampak siswa kurang tertarik mengikuti proses belajar dan memiliki anggapan pelajaran IPS adalah pelajaran "lunak" membutuhkan hapalan yang dalam waktu singkat sebelum menghadapi tes atau ujian. Anggapan ini akan hilang apabila terdapat perubahan orientasi guru dalam pembelajaran IPS dan memahami pembelajaran IPS yang powerful dan bermakna melalui penggunaan model dan strategi pembelajaran yang tepat.

Model pembelajaran berbasis proyek (project based learning/PBL) sebagai salah satu model pembelajaran inovatif yang berbasis pada peserta didik (student centre) dapat digunakan dan dipilih oleh guru sebagai salah satu alternatif metode pembelajaran yang akan memberikan "warna" baru dalam pembelajaran dari yang umumnya cenderung konvensional. Menurut George Lucas Educational Foundation (2005) bahwa Project-based learning is a dynamic approach to teaching in which student explore real world problems and challenges. With this type of active and engaged 
learning, students are inspired to obtain a deeper knowledge of the subjects they're studying. Melalui $P B L$, peserta didik mengeksplorasi permasalahan dan tantangan di dunia nyata sehingga peserta didik lebih lama memiliki daya ingat dan pemahaman terhadap yang mereka pelajari. Dengan pembelajaran berbasis proyek yang termasuk jenis pembelajaran yang melibatkan peserta didik secara aktif, maka akan terinspirasi untuk memperoleh pengetahuan yang lebih dalam mata pelajaran yang mereka pelajari.

Menurut Boss \& Krauss (2007) pembelajaran berbasis proyek adalah strategi tertentu untuk mengubah atau membalikkan wajah kelas tradisional. Maksudnya adalah melalui pembelajaran ini, maka pembelajaran di kelas yang umumnya menggunakan pembelajaran konvensional menjadi lebih inovatif. Lebih lanjut dikemukakan oleh Boss \& Krauss (2007, hlm 12) “In project-based learning. Students investigate open-ended questions and apply their knowledge to produce authentic products. Projects typically allow for student choice, setting the stage for active learning and teamwork". Dalam pembelajaran berbasis proyek, peserta didik melakukan investigasi (penyelidikan) melalui pertanyaan terbuka, menerapkan pengetahuan untuk menghasilkan produk. Selain itu, dalam pembelajaran ini "disetting" peserta didik yang lebih aktif dalam pembelajaran dengan bekerja sama dalam satu kelompok. Fokus pembelajaran berbasis proyek bertujuan agar siswa dalam pembelajaran dapat mengembangkan pengetahuan dan keterampilannya melalui proses penyelidikan yang terstruktur dan menghasilkan produk berbeda dengan pembelajaran tradisional yang sekedar mendapat teoriteori yang dihapal saja.

Peserta didik belajar dengan terlibat dalam proyek-proyek dunia nyata dan setiap aspek perubahan pengalaman mereka. Pembelajaran model ini juga menyebabkan pergeseran peran guru tidak lagi sebagai ahli menyampaikan konten, atau hanya membagikan informasi dalam potongan yang kecil. Penerapan model pembelajaran ini dapat menjadikan suasana pembelajaran di kelas menjadi lebih "hidup" dan menyenangkan. Melalui penerapan model ini, peserta didik diajak mengembangkan kemampuan berpikir tingkat tinggi (high order thinking) dengan disodorkan permasalahan dalam kehidupan nyata dan guru memfasilitasi peserta didik untuk belajar dengan cara-cara yang relevan dengan masalah tersebut.

Lingkungan belajar berbasis proyek menyebabkan adanya perubahan positif dari guru dan peserta didik tentang kepedulian terhadap lingkungan. Perilaku mereka meningkat dalam aksi dan aktivitas kepedulian terhadap lingkungan. Neni Suharjani (2014) mengemukakan bahwa peningkatan pengetahuan dan pemahaman peserta didik dapat menghasilkan perubahan dalam sikap dan perilaku terhadap lingkungan melalui penggunaan model pembelajaran berbasis masalah. Berdasarkan penelitian Muhaimin (2014), dikemukakan bahwa model $P B L$ yang dikembangkan berbasiskan lingkungan hidup lokal efektif untuk meningkatkan kompetensi ekologis siswa berupa aspek pengetahuan, sikap, sedangkan aspek keterampilan dan partisipasi masih membutuhkan proses sangat panjang dan komitmen dari berbagai pihak.

SMPN 1 Kemang Kabupaten Bogor merupakan sekolah yang terletak di daerah Kecamatan Kemang Kabupaten Bogor. Kabupaten Bogor memiliki beragam permasalahan yang ditemui terkait tentang sikap dan perilaku peserta didik terhadap lingkungan diantaranya rendahnya disiplin peserta didik dalam membuang sampah pada tempatnya. Hal tersebut mengakibatkan lingkungan kelas dan lingkungan sekolah hanya nampak bersih pada pagi hari, namun menjelang istirahat sekolah hingga waktu pulang sekolah, terlihat banyak sampah berserakan. Indikasi lainnya tentang sikap dan perilaku peserta didik yang masih nampak kurang peduli terhadap lingkungan adalah maraknya 
perilaku "vandalisme" terlihat dari banyaknya coretan-coretan spidol, tip-ex, pulpen pada beberapa bagian dinding kelas. Selain itu, coretan tip-ex, pulpen juga banyak ditemui di meja dan bangku kelas. Meskipun di sekolah sudah disediakan tempat sampah organik dan anorganik di luar kelas, namun peserta didik nampak belum memanfaatkan sesuai peruntukannya.

Kenyataan tersebut tentu sangat tidak sesuai dengan harapan pencapaian tujuan pendidikan IPS khususnya maupun bagi tercapainya tujuan pendidikan nasional, mengingat tujuan pendidikan IPS sebagai mata pelajaran yang mempersiapkan peserta didik sebagai warganegara yang memiliki pengetahuan dan pemahaman tentang masyarakat dan bangsanya, religius, jujur, demokratis, kreatif, analitis, senang membaca, memiliki kemampuan belajar, rasa ingin tahu, peduli dengan lingkungan sosial dan fisik, berkontribusi terhadap pengembangan kehidupan sosial budaya, serta berkomunikasi secara produktif. Dengan menggunakan model PBL dalam pembelajaran IPS di SMPN 1 Kemang Kabupaten Bogor diharapkan peserta didik dapat mengembangkan sikap kepedulian terhadap lingkungannya.

Berdasarkan hal tersebut, rumusan masalah penelitiannya yaitu: Apakah terdapat pengaruh penerapan pembelajaran IPS berbasis $P B L$ terhadap pengembangan sikap peduli peserta didik terhadap lingkunganan siswa terhadap lingkungan?

\section{METODE PENELITIAN}

Penelitian ini menggunakan pendekatan kuantitatif dengan metode penelitian eksperimen kuasi (quasi experiment). Pendekatan kuantitatif digunakan untuk melihat perbedaan efektifitas model dengan mengujikan satu model pembelajaran proyek dalam pembelajaran IPS di kelas eksperimen dan penggunaan model lain di kelas kontrol. Penelitian ini ingin menguji hipotesis yang diajukan untuk melihat efektifitas penerapan model tertentu. Instrumen penelitian ini terdiri dari satu instrumen utama yaitu data sikap peduli terhadap lingkungan menggunakan angket menggunakan skala likert, dan instrumen penunjang digunakan angket respon guru dan peserta didik, observasi pembelajaran di lingkungan kelas dan sekolah, dan wawancara terhadap guru dan peserta didik. Data penunjang akan digunakan untuk mendeskripsikan hasil data penelitian yang diperoleh dari angket sikap peduli terhadap lingkungan. Tahapan analisis data yang dilakukan adalah: Uji Normalitas, Uji Homogenitas, Uji Perbedaan dua rata-rata, dan Dan perhitungan gain ternormalisasi. Statistik yang digunakan dalam menguji rata-ratanya dilakukan uji normalitas dan homogenitas dengan bantuan program SPSS 20 For Windows pada taraf signifikansi $5 \%$.

\section{HASIL DAN PEMBAHASAN}

Sebelum penelitian ini dilaksanakan, dilakukan studi pendahuluan pada sekolah dan kelas yang menjadi tempat penelitian untuk menjajagi informasi awal yang dibutuhkan sebagai data dalam penelitian ini. Data primer dalam penelitian ini berasal dari angket sikap kepedulian lingkungan, kemudian sebagai data sekunder adalah hasil observasi terhadap pelaksanaan pembelajaran dan keadaan lingkungan sekolah tempat berlangsungnya penelitian ini.

Sampel yang terpilih dalam penelitian ini diambil dari kelompok-kelompok yang telah terbentuk secara alamiah yaitu kelas, dan memiliki kemungkinan yang sama untuk dipilih. Sebagai sampel dalam penelitian adalah kelas VII yang terdiri dari sembilan rombongan belajar (rombel). Kelas yang ditentukan untuk digunakan dalam penelitian ini adalah kelas VII-9 sebagai kelas eksperimen dan kelas VII-5 sebagai kelas kontrol. Penentuan pemilihan kelas VII-9 dan kelas VII-5 didasarkan pada hasil Ujian Akhir Semester (UAS) semester ganjil tahun pelajaran 2014/2015 khusus mata pelajaran IPS, dimana kedua kelas ini 
memiliki nilai Relatif homogen dan jumlah peserta didik yang sama yaitu masingmasing kelas berjumlah 40 siswa.

Hasil observasi awal dalam penelitian ini, diketahui bahwa proses pembelajaran IPS yang dilakukan guru masih menekankan pada hasil pembelajaran dan bukan pada proses pembelajaran. Hal ini terlihat dari hal-hal sebagai berikut : 1) guru lebih aktif dalam proses pembelajaran dibandingkan peserta didik, 2) metode mengajar konvensional banyak menggunakan ceramah, 3) penyampaian guru dalam proses pembelajaran lebih mementingkan pada penyampaian konsep-konsep yang tertera dalam buku teks daripada mengarahkan peserta didik pada pembelajaran yang bermakna dan berfungsi dalam kehidupan siswa sehari-hari secara nyata (real world) dengan mengaitkan konsep-konsep dalam buku teks dengan kehidupan nyata seharihari yang terdapat di sekitar lingkungaan siswa (di rumah, sekolah, maupun kehidupan masyarakat), 4) kurang tercipta pembel-ajaran yang menyenangkan dan memberikan kebebasan siswa untuk berperilaku aktif dengan berkreasi dalam mengkontruksi pemikirannya, 5) kurang memberikan stimulus (rangsangan) kepada siswa untuk berfikir tingkat tinggi (High Order Thinking) dengan berpikir kritis, kreatif dalam memahami dan menerapkan nilai-nilai yang berguna bagi dirinya dan bagi orang lain.

Berkaitan obyek kajian pendidikan IPS, salah satunya adalah tentang segala perilaku manusia dalam berinteraksi dengan lingkungannya, baik lingkungan alam maupun lingkungan sosial. Pembelajaran IPS tentang hubungan antara manusia dan lingkungannya dan untuk mengatasi isu-isu lingkungan melalui transfer pengetahuan, sikap dan keterampilan bertujuan agar peserta didik memiliki kemampuan (skill) dalam bersikap dan bersahabat dengan lingkungan. Sikap dan perilaku peserta didik dalam menjaga dan melesatarikan lingkungan hidupnya dapat terbentuk secara efektif melalui pembel- ajaran yang bermakna dan melibatkan siswa secara aktif daripada hanya melalui penyampaian konsep-konsep saja dengan metode pembelajaran yang monoton dan membosankan.

Proses pembelajaran sebagai perlakuan (treatment) dilakukan di kelas eksperimen menggunakan model $P B L$ direncanakan dilaksanakan selama 6 kali pertemuan (3 pekan) dengan alokasi waktu masing-masing pertemuan selama $2 \times 45$ menit (2 jam pelajaran). Sebelum guru mata pelajaran yang menjadi guru model dalam menerapkan PBL di kelas eksperimen dan guru model yang menerapkan model pembelajaran berbasis masalah di kelas kontrol, terlebih dahulu dipaparkan mengenai konsep model pembelajaran berbasis proyek dengan rencana/skenario pembelajaran.

Dalam proses pembelajaran, guru membagi siswa dalam 8 kelompok yang masing-masing beranggotakan 5 orang. Setiap kelompok akan membuat proyeknya masing-masing sesuai desain proyek yang telah ditetapkan pada pertemuan sebelumnya. Setiap kelompok melaksanakan kegiatan proyek dan menyusun jadwal pelaksanaannya. Setelah mendapat arahan dari guru, tiap-tiap kelompok melaksanakan proyek yang sudah didesain bersama sesuai jadwal yang telah ditetapkan. Output dari proyek yang dilaksanakan adalah peserta didik menghasilkan produk sebagai hasil kerjanya. Beberapa kegiatan proyek yang didesain oleh kelas eksperimen adalah : 1) Penelitian tentang permasalahan kebersihan lingkungan sekolah; 2) Kampanye lingkungan untuk membuang sampah di tempatnya; 3) Pembelajaran praktek memilah/ mengelompokkan sampah organik dan anorganik pada kelas; 4) Pembuatan taman kelas atau penghijauan di lingkungan kelas; dan 5) Proyek Pameran Hasil Karya peserta didik untuk meningkatkan kepedulian peserta didik dalam menjaga dan memelihara kebersihan, keindahan serta kerapihan lingkungan sekolah. 
Peserta didik melakukan pengerjaan proyek di kelas selama proses pembelajaran di pertemuan kedua hingga pertemuan keempat. Selama proses pembelajaran berlangsung peran guru adalah memfasilitasi dan memberikan pengawasan terhadap pelaksanaan kemajuan proyek serta memberikan bantuan terhadap peserta didik yang membutuhkan agar dapat menyelesaikan proyek sesuai program dan waktu yang telah ditetapkan. Guru melakukan pencatatan terhadap setiap kemajuan proses pelaksanaan proyek. Kegiatan pertemuan keempat pada akhir sesi diakhiri dengan persiapan untuk membuat pameran hasil karya produk peserta didik baik berupa display hasil karya dari bahan bekas pakai maupun produk berupa presentasi. Pada kegiatan pameran hasil karya, guru dan peserta didik kelas eksperimen mengundang beberapa siswa kelas lain untuk melihat hasil karya pembelajaran mereka.

Hasil penelitian yang mencoba mengungkap tentang upaya pengembangan sikap kepedulian peserta didik terhadap lingkungan melalui penerapan pembelajaran IPS berbasis proyek menunjukkan hasil positif. Kesimpulan yang didapat dari hasil penelitian bahwa terdapat perbedaan yang signifikan antara rata-rata skor pengukuran awal (pre-tes) dan pengukuran akhir (pos-tes) setelah mengikuti pembelajaran dengan menerapkan model pembelajaran berbasis proyek di kelas eksperimen. Berdasarkan pengujian data, dapat diketahui bahwa nilai $\mathrm{t}$ hitung $=6,405>$ $\mathrm{t}_{\text {tabel }}=2,021$ atau nilai sig (2-tailed $)=0,000<$ 0,05, maka dapat disimpulkan bahwa $\mathrm{H}_{\mathrm{O}}$ ditolak sedangkan Ha diterima. Dengan demikian, terdapat perbedaan sikap kepedulian peserta didik terhadap lingkungan pada kelas eksperimen yang menerapkan model $P B L$.

Demikian pula di kelas kontrol, terdapat perbedaan yang signifikan antara rata-rata skor pengukuran awal (pre-tes) dan pengukuran akhir (pos-tes) setelah mengikuti pembelajaran dengan menerap- kan model pembelajaran berbasis masalah. Berdasarkan pengujian data dapat diketahui bahwa nilai $\mathrm{t}$ hitung $=14,747>\mathrm{t}$ tabel $=2,021$ atau nilai sig (2-tailed) $=0,000<$ 0,05, maka dapat disimpulkan bahwa $\mathrm{Ho}_{\mathrm{O}}$ ditolak sedangkan Ha diterima. Dengan demikian, terdapat perbedaan sikap kepedulian peserta didik terhadap lingkungan pada kelas kontrol yang menerapkan model pembelajaran berbasis masalah.

Hasil pengujian hipotesis untuk mencari perbedaan rata-rata skor atas sikap kepedulian lingkungan antara kelas eksperimen dan kelas kontrol dimana dapat diketahui bahwa nilai $\mathrm{t}_{\text {hitung }}=0,617<$ $\mathrm{t}$ tabel. $\mathrm{T}_{\text {tabel }}=1,990$ atau nilai sig $(2$-tailed $)=$ $0,539>0,05$, maka Ho diterima sedangkan Ha ditolak. Dengan demikian, tidak terdapat perbedaan sikap kepedulian peserta didik terhadap lingkungan antara kelas eksperimen yang menggunakan pembelajaran berbasis proyek dengan kelas kontrol yang menggunakan pembelajaran berbasis masalah. Hal ini bisa disimpulkan bahwa penerapan model pembelajaran berbasis proyek dan berbasis masalah cukup efektif untuk meningkatkan kepedulian peserta didik terhadap lingkungan, karena kedua model ini termasuk model pembelajaran yang setara dan keduanya tergolong pembelajaran inovatif yang mendorong keaktifan peserta didik karena menggunakan pendekatan pembelajaran berpusat pada peserta didik (student centre).

Berdasarkan pembahasan hasil penelitian, dapat dikatakan bahwa efektifitas pengembangan sikap kepedulian peserta didik terhadap lingkungan tidak terlepas dari penggunaan model pembelajaran oleh guru yang menentukan keberhasilan dalam proses pembelajaran IPS. Penerapan model pembelajaran yang efektif dalam pembelajaran IPS yang tidak berfokus hanya pada pengembangan aspek pengetahuan semata, dapat menumbuhkan kesadaran dan kepedulian siswa selaku peserta didik tentang kelestarian lingkungan. Menurut 
para ahli pendidikan lingkungan, kebanyakan orang tidak menggunakan kesadaran lingkungan mereka untuk berperilaku peduli terhadap lingkungan. Karena itu, para ahli percaya bahwa ada kesenjangan antara "pola kognitif dan perilaku" manusia (Kilinc, 2010, hlm. 495). Diperlukan suatu program berorientasi aksi untuk untuk mengembangkan perilaku peduli lingkungan.

Berdasarkan hasil observasi di kelas eksperimen setelah perlakuan penerapan model pembelajaran berbasis proyek, sikap kepedulian siswa sudah mulai terbangun dengan baik terlihat dari partisipasi peserta didik yang mulai tumbuh dengan aksi sosial (social action) yang mereka lakukan dengan kerja bakti bersama-sama mengecat meja dan kelas yang penuh coretan, kedisiplinan kerja piket kelas, mengambil sampah di areal terdekat serta membuangnya di tempat yang disediakan, dan bertanggung jawab terhadap kebersihan kelas dengan tidak menyimpan sampah di dalam laci meja. Sikap kepedulian peserta didik terhadap lingkungan yang nampak meningkat setelah mengikuti pembelajaran menunjukkan bahwa penerapan model pembelajaran berbasis proyek memiliki efektifitas untuk meningkatkan sikap kepedulian terhadap lingkungan. Hal ini menegaskan yang dikemukakan oleh Kilinc (2010) bahwa lingkungan belajar berbasis proyek menyebabkan adanya perubahan positif dari guru dan peserta didik tentang kepedulian terhadap lingkungan. Selain aspek pengetahuan, kompetensi sikap dan perilaku peduli terhadap lingkungan juga perlu ditumbuhkan dan dimiliki oleh peserta didik. Dalam kaitan dengan hal tersebut, terdapat proses mental yang terkait antara komponen sikap dan nilainilai yang dapat mengarahkan perilaku. Iozy berpendapat (Polley \& O'Connor, 2000) bahwa "to adress the values and attitudes in developing environmentally concious behavior, it has been suggested that the key entry point for environmental education". Berkenaan dengan perilaku seseorang terhadap lingkungan terdapat berbagai faktor yang mempengaruhinya. Menurut Made Putrawan (2014), sebelum seseorang bertindak dengan sengaja terhadap masalah lingkungan tertentu harus memiliki kemampuan dan pengetahuan tentang isu lingkungan, kemauan bertindak (desire to act) yang dipengaruhi oleh faktor-faktor personal seperti sikap, locus of control, dan tanggung jawab personal terhadap lingkungan. Sikap berkaitan nilai moral terhadap lingkungan harus ditumbuhkan terus menerus sehingga akan terbentuk karakter kepribadian peserta didik yang memiliki kesadaran dan kepedulian terhadap lingkungan.

Dalam pelaksanaan penelitian ini, ditemui beberapa kendala implementasi model di lapangan. Kendala-kendala yang ditemui dalam implementasi Model PBL sebagai berikut.

Pertama, alokasi waktu yang kurang. Masalah alokasi waktu menjadi kendala utama dalam penerapan model. Meski alokasi waktu telah dipersiapkan dengan matang dalam rancangan skenario pembelajaran yang disusun juga berdasarkan hasil diskusi dengan guru model, tetapi pada saat praktek di lapangan masih juga ditemui beberapa kendala perihal waktu. Di kelas eksperimen, kendala perihal waktu dijumpai dalam sintaks pelaksanaan proyek, sehingga pembuatan produk di sekolah terkesan memiliki waktu yang sangat sempit dan terbatas. Sedangkan kendala di kelas kontrol ditemui pada sesi tertentu khususnya dalam sintaks siswa mempresentasikan hasil penyelidikan dan solusi untuk mengatasi permasalahan dan pada saat diskusi.

Kedua, dalam menerapkan model pembelajaran berbasis proyek di kelas eksperimen memiliki tahapan-tahapan (sintaks) masing-masing yang rangkaian prosesnya membutuhkan pemahaman dan waktu persiapan dari guru yang sangat matang. Karena guru model belum terbiasa menerapkan pembelajaran yang konstruktivistik, dan saat pembelajaran lebih banyak 
menerapkan pembelajaran konvensional dengan metode ceramah penyampaian konsep sehingga belum terbiasa dalam menjalankan rangkaian proses sintaks penerapan model pembelajaran berbasis proyek dengan waktu yang sangat panjang dan membutuhkan waktu pertemuan yang cukup lama. Intensitas pertemuan dan keberlanjutan setiap tahapan (sintaks) dipandang oleh guru membutuhkan alokasi waktu dan persiapan yang cukup agar dapat menjalankan proses tersebut dengan baik.

Ketiga, dalam menerapkan model pembelajaran berbasis proyek di kelas eksperimen membutuhkan keterampilan khusus dan pemahaman terhadap filosofis karakteristik pembelajaran IPS berbasis konstruktivistis. Guru harus membiasakan diri untuk membuka wawasan pengetahuan melalui pemahaman terhadap ide-ide pemikiran paradigma pembelajaran konstruktivistik kemudian berlatih melakukan pembelajaran yang inovatif sehingga memiliki kualifikasi dan menguasai keterampilan dalam menerapkan pembelajaran berbasis proyek maupun berbasis masalah. Pemahaman guru yang masih kurang dalam filosofis konstruksi model pembelajaran ini, akan menyebabkan guru kesulitan memaknai proses penerapan dalam pembelajaran IPS, sehingga pola berpikir guru belum beranjak dari paradigma behavioristik yang mendominasi pembelajaran yang dilakukan di kelas.

Keempat, keberhasilan penerapan model pembelajaran berbasis proyek tergantung dari pemahaman yang utuh dari seorang guru dalam menerapkan seluruh rangkaian tahapan (sintaks). Tahapan-tahapan (sintaks) merupakan satu rangkaian kesatuan yang sistematis dan tidak terpisahkan satu sama lain. Sintaks dalam model ini harus dilaksanakan seluruhnya dan prosesnya dilaksanakan sesuai dengan tahapannya. Guru harus memiliki pemahaman mendasar dari tiaptiap langkah penerapan yang dilakukan dalam sintaks model pembelajaran berbasis proyek agar pelaksanaan tahapan model pembelajaran ini menjadi efektif bermakna.

Kelima, saat melakukan kolaborasi, siswa terlihat masih nampak kurang percaya diri dalam menjalankan aktifitas pembelajaran model proyek ini. Masih terlihat ada siswa yang pasif dan bekerja saling mengandalkan satu sama lain. Pembelajaran berbasis proyek ini merupakan pembelajaran yang berpusat pada siswa (student centered) dan bukan berpusat pada guru, sehingga siswa harus memiliki pemahaman diri bahwa siswa sebagai subyek belajar. Mereka bukan penerima materi pembelajaran berupa konsep-konsep dari guru sebagaimana biasa dilakukan dalam pembelajaran konvensional selama ini. Pembelajaran model proyek yang dilakukan menuntut siswa aktif dalam mengembangkan kreatifitasnya dan merangsang proses berpikir dengan memicu aktivasi semua indera yang dimiliki siswa. Siswa belajar melalui mendengar, melihat, dan melakukan (learning by doing) membuat indera siswa lebih banyak aktif, dan terlibat penuh dalam seluruh proses pembelajaran. Kebiasaan siswa yang saling mengandalkan, dan pasif dikarenakan siswa belum terbiasa dan belum memiliki pemahaman tentang pembelajaran inovatif seperti pembelajaran berbasis proyek ini.

Keenam, adanya keraguan guru dalam menerapkan model proyek ini dikarenakan masih berorientasi pada hasil akhir berupa nilai akademik. Penekanan guru pada proses pembelajaran yang bermakna dan bukan pada hasil akhir berupa nilai akademik akan mempengaruhi keberhasilan penerapan model pembelajaran berbasis proyek. Proses pembelajaran yang masih menekankan pada penyampaian konsepkonsep dengan ceramah dan berorientasi pada hasil akhir berupa nilai akademik dikarenakan ujian bersama di setiap akhir semester yang diselenggarakan secara sentralistik dari dinas, materi soalnya sebagian besar menekankan pada aspek ingatan berupa pengetahuan dan 
pemahaman, sehingga guru dalam melaksanakan pembelajarannya lebih berfokus agar peserta didik memiliki penguasaan materi agar dapat menyelesaikan soal-soal penilaian akhir semester tersebut dan mengabaikan pada menciptakan proses pembelajaran yang bermakna, kreatif dan menyenangkan.

Berdasarkan angket respon guru setelah melaksanakan seluruh rangkaian proses pembelajaran dengan menggunakan model pembelajaran berbasis proyek dapat dikemukakan beberapa hal sebagai berikut : 1) Respon guru terhadap tahapan-tahapan (sintaks) dalam implementasi model pembelajaran cukup baik. Guru berpendapat bahwa sintaks dalam implementasi model pembelajaran berbasis proyek cukup menantang dalam mengajar. Model ini dianggap guru sebagai sesuatu hal yang baru dan cukup memberikan warna baru dalam pelaksanaan proses pembelajaran IPS. Karena proses pembelajaran IPS yang umumnya dikenal oleh guru selama ini hanya sebatas penerapan metode konvensional yaitu dengan ceramah penyampaian konsep-konsep dan pengajaran berpusat pada guru (teacher centered) dengan materi bersumberkan hanya dari buku paket; 2) Respon guru terhadap komponen perangkat pembelajaran dalam implementasi model pembelajaran berbasis proyek ini meliputi, RPP, bahan ajar, LKS, Jadwal pelaksanaan proyek, serta penilaian merupakan suatu proses yang sangat menantang dalam proses pembelajaran IPS; 3) Kegiatan Pembelajaran IPS dengan melakukan metode proyek penyelidikan (inkuiri), menghasilkan dan memamerkan hasil karya (produk), aksi sosial dalam kegiatan pembelajaran bertemakan interaksi manusia dengan lingkungan merupakan sesuatu hal baru bagi guru yang sangat menantang dalam menciptakan suasana pembelajaran yang lebih bermakna, kreatif, dan menyenangkan bagi siswa; 4) Guru memandang bahwa proses pembelajaran IPS dengan menerapkan model pembelajaran berbasis proyek memiliki keunggulan-keunggulan diantaranya: peserta didik dapat berperan aktif dalam pembelajaran, peserta didik dapat mengembangkan kreatifitas dan memunculkan rasa percaya diri, dan dapat memunculkan kerjasama antar peserta didik dalam memecahkan permasalahan berkaitan dengan lingkungan di sekolah; dan 5) Rekomendasi yang dapat diberikan guru sebagai respon setelah menerapkan model pembelajaran berbasis proyek adalah model tersebut dianggap cukup baik diterapkan sebagai model pembelajaran utama yang dilaksanakan dalam pembelajaran IPS karena dapat mengembangkan potensi diri peserta didik yang tidak terbatas pada aspek pengetahuan saja melainkan juga pada aspek sikap dan keterampilan. Menurut pendapat guru, hal ini disebabkan karena peserta didik terlibat aktif secara langsung dengan memunculkan ide-ide baru untuk menyelesaikan masalah-masalah di dunia nyata dengan mengerjakan suatu proyek yang menghasilkan suatu karya/produk.

Selain hal tersebut di atas, respon peserta didik terhadap aspek-aspek pembelajaran secara keseluruhan juga menunjukkan sikap positif. Peserta didik merasa termotivasi dalam menyelesaikan tugas-tugas menantang untuk mengembangkan rasa percaya diri dan mengasah kreatifitasnya dalam menemukan solusi. Selain terkait hal proses pembelajaran, berdasarkan data yang dikumpulkan dari angket respon peserta didik setelah mengikuti pelaksanaan model pembelajaran berbasis proyek dapat diketahui halhal spesifik lainnya yang dideskripsikan berikut ini.

Pertama, Seluruh peserta didik di kelas eksperimen merespon positif dan senang terhadap penerapan model pembelajaran berbasis proyek dalam pembelajaran IPS tentang materi interaksi manusia dengan lingkungan. Selama ini menurut peserta didik bahwa walaupun guru sudah berupaya menggunakan metode dan media beragam dalam pembelajaran namun masih 
didominasi dengan penggunaaan metode ceramah dalam pembelajaran IPS. Selanjutnya, alasan yang dikemukakan peserta didik menyenangi penerapan model pembelajaran berbasis proyek dalam pembelajaran IPS

Kedua, terhadap tugas-tugas proyek yang diberikan melalui penerapan model $P B L$, respon peserta didik hampir seluruhnya menyatakan bahwa tugas-tugas yang diberikan cukup menantang untuk menyelesaikannya.

Ketiga, penerapan model pembelajaran berbasis proyek ini memberikan manfaat atau kegunaan bagi peserta didik. Pernyataan alasan yang dikemukakan mengenai manfaat atau kegunaan yang dirasakan peserta didik setelah mengikuti proses pembelajaran yang menerapkan model pembelajaran berbasis proyek.

Pelaksanaan penelitian tentang penerapan model pembelajaran berbasis proyek untuk mengembangkan kepedulian siswa terhadap lingkungan memiliki keterbatasan-keterbatasan sebagai berikut.

Pertama, kendala waktu pelaksanaan yang relatif kurang karena intensitas pertemuan efektif di kelas hanya selama enam kali pertemuan (3 pekan) dan satu pekan untuk observasi awal (studi pendahuluan). Pembelajaran berbasis proyek membutuhkan waktu cukup panjang mengingat sintaksnya mensyaratkan adanya tahapan dari mulai mendesain proyek hingga finalisasi produk membutuhkan waktu yang cukup lama. Masalah waktu pelaksanaan merupakan hal yang membatasi dalam penelitian ini, mengingat jika waktu pelaksanaan diperpanjang, maka waktu efektif belajar siswa akan kembali tersita dan dapat mengganggu rencana program pembelajaran yang telah disusun sebelumnya oleh guru mata pelajaran IPS di sekolah tersebut. Selain itu, kendala waktu persiapan juga merupakan hal yang menjadi keterbatasan dalam penelitian ini. Waktu persiapan idealnya harus lebih lama untuk mendiskusikan persiapan pelaksanaan penelitian dengan guru model kemudian melakukan ujicoba model secara terbatas sebelum diterapkan di kelas eksperimen.

Kedua, terbatasnya sumber-sumber informasi seperti buku-buku di perpustakaan, padahal sumber informasi variatif berupa buku-buku merupakan unsur penunjang yang penting dalam proses pelaksanaan pembelajaran berbasis proyek. Selain itu, jaringan wifi internet di sekolah yang sudah tersedia, namun karena keterbatasan sarana laptop dan gadget yang dimiliki peserta didik menjadikan sarana internet sekolah tidak dapat dimanfaatkan secara optimal.

Ketiga, guru juga harus bekerja keras membangkitkan motivasi belajar peserta didik untuk aktif dalam mengikuti pembelajaran sesuai tujuan pembelajaran berbasis proyek, karena sebelumnya lebih banyak belajar dengan suasana pembelajaran konvensional yang banyak menerima input informasi dari guru secara satu arah. Pembelajaran berbasis proyek merupakan pembelajaran yang berpusat pada peserta didik. Peran guru hanya sebagai fasilitator yang membimbing dan mengarahkan peserta didik dalam proses pembelajaran. Peserta didik nampaknya belum terbiasa belajar dengan sistem pembelajaran model baru, dimana peran guru yang semula mendominasi bergeser kepada peserta didik yang lebih dominan berperan secara aktif dalam pembelajaran.

Keempat, keterbatasan kemampuan siswa dalam melakukan pengamatan dan bekerja secara sistematis, terstruktur dan dalam melaksanakan presentasi hasil pengamatan di depan kelas, sehingga guru harus banyak menyediakan waktu dalam membimbing dan mengarahkan agar dapat menumbuhkan rasa percaya diri peserta didik dalam menerapkan model pembelajaran berbasis proyek, sehingga tujuan pembelajaran yang telah direncanakan dapat tercapai dengan baik.

Kelima, keterbatasan pelaksanaan penerapan model pembelajaran berbasis proyek dikarenakan kurangnya pemaham- 
an guru model akan model pembelajaran yang inovatif. Guru cenderung nampak masih ragu-ragu dalam melaksanakannya dan lebih terbiasa dengan penggunaan metode konvensional. Orientasi guru masih nampak pada hasil akhir dengan output nilai dan belum berorientasi pada proses pembelajaran yang mengembangkan aspek lain dari diri peserta didik.

\section{SIMPULAN}

Berdasarkan hasil dan pembahasan penelitian, maka dapat ditarik beberapa simpulan penelitian secara keseluruhan sesuai dengan permasalahan penelitian yang dikemukakan sebagai berikut : 1) Penerapan pembelajaran yang inovatif seperti pembelajaran berbasis proyek maupun berbasis masalah menunjukkan efektifitas dalam meningkatkan kepedulian peserta didik terhadap lingkungan ditunjukkan dengan adanya perbedaan yang signifikan atas pengukuran awal (pretest) dan pengukuran akhir (post-test) di kelas eksperimen maupun di kelas kontrol. Peningkatan skor rata-rata yang lebih besar atas pengukuran awal (pre-test) dan pengukuran akhir (post-test) sikap kepedulian peserta didik terhadap lingkungan terdapat di kelas eksperimen dibandingkan kelas kontrol sesudah diberikan perlakuan (treatment). Tidak adanya perbedaan yang signifikan pada pengukuran akhir (posttest) tentang sikap kepedulian peserta didik terhadap lingkungan antara kelas eksperimen dengan kelas kontrol dapat disebabkan karena keduanya cenderung setara yang merupakan pembelajaran inovatif berbasis konstruktivisme dan berpusat pada peserta didik (student centered); 2) Sikap kepedulian peserta didik terhadap lingkungan nampak meningkat setelah mengikuti pembelajaran terlihat dari hasil observasi diantaranya munculnya kedisiplinan dalam membuang sampah di tempatnya, kerja bakti membersihkan coret-coretan meja dan dinding kelas, dan mulai aktif menjalankan piket kelas. Sikap kepedulian lingkungan yang mulai terbentuk bukanlah sesuatu yang bersifat statis, tetapi membutuhkan upaya terus menerus dan proses yang lama agar tertanam menjadi suatu karakter kepribadian peserta didik. Dibutuhkan sinergitas peran pihak lain seperti kepala sekolah, orangtua, dan masyarakat. untuk menjadikan sikap kepedulian peserta didik yang telah berkembang menjadi suatu karakter pribadi. Menjadikan kesadaran dan kebiasaan yang baik dalam membuang sampah pada tempatnya sebagai suatu karakter yang tertanam dalam diri peserta didik; 3) Penerapan pembelajaran berbasis proyek dalam pembelajaran IPS mendapatkan respon yang positif dari peserta didik, karena dapat memotivasi peserta didik melalui pemberian tugastugas proyek yang menantang untuk memberikan kesempatan pada peserta didik mengembangkan rasa percaya diri serta mengasah daya kreatifitas. Aktifitas siswa dalam pembelajaran meningkat, terlihat dari keterlibatan siswa secara aktif dan mandiri dalam penyelesaian tugastugas proyek selama proses pembelajaran. Secara umum, peserta didik menganggap bahwa penerapan model pembelajaran berbasis proyek yang dilakukan guru sebagai sesuatu yang berbeda dari pembelajaran yang sering dilakukan guru pada umumnya, yaitu penggunaan metode ceramah yang lebih dominan dalam penyampaian konsep-konsep dan kurang melibatkan peserta didik untuk berpartisipasi aktif dalam pembelajaran; 4) Guru merespon positif dan memandang bahwa proses pembelajaran IPS dengan menerapkan model pembelajaran berbasis proyek memiliki keunggulan-keunggulan diantaranya dapat meningkatkan pengetahuan dan pemahaman guru tentang sintaks model pembelajaran yang inovatif, dan meningkatkan kemampuan serta keterampilan guru dalam mengelola, mengorganisasikan, dan melaksanakan pembelajaran di kelas. Selain itu melalui penerapan pembelajaran berbasis proyek, peserta didik dapat berperan aktif dalam pembelajaran, dapat 
mengembangkan daya kreatifitas, memunculkan rasa percaya diri, dan meningkatkan saling kerjasama antar peserta didik dalam memecahkan permasalahan berkaitan dengan lingkungan di sekolah; 5) Model pembelajaran baik berbasis proyek maupun berbasis masalah baik untuk dilaksanakan dalam pembelajaran IPS, karena kedua model pembelajaran tersebut mendorong keaktifan peserta didik untuk dapat mengembangkan kompetensi dirinya tidak terbatas pada aspek pengetahuan saja melainkan juga pada aspek sikap dan keterampilan. Selain itu, melalui penerapan model pembelajaran ini, peserta didik diberi ruang untuk membangun makna pengetahuan dari situasi pembelajaran yang dilakukan dan peserta didik terlibat aktif secara langsung dengan memunculkan ide-ide baru untuk menyelesaikan masalah-masalah di dunia nyata dan mengerjakan suatu proyek untuk menghasilkan suatu karya/produk; 6) Kendalakendala yang ditemui dalam penerapan pembelajaran berbasis proyek adalah Implementasi model pembelajaran berbasis proyek membutuhkan alokasi waktu dan persiapan guru yang cukup lama agar dapat berjalan dengan baik. Keterbatasan alokasi waktu dan efisiensi waktu merupakan kelemahan dalam penerapan model pembelajaran ini. Selain itu, keterampilan dan cara pandang guru terhadap model pembelajaran yang inovatif juga amat diperlukan agar implementasi model berjalan efektif. Peran guru amat strategis agar dapat menerapkan pembelajaran ini secara efektif, karena pembelajaran berbasis proyek merupakan pembelajaran yang berpusat pada peserta didik (student centered), sedangkan peran guru hanya sebagai fasilitator yang membimbing dan mengarahkan peserta didik dalam proses pembelajaran. Guru dan peserta didik nampaknya belum terbiasa belajar dengan sistem pembelajaran model baru dimana peran guru yang semula mendominasi bergeser kepada peserta didik yang lebih dominan berperan secara aktif dalam pembelajaran. Peserta didik nampak masih terbiasa dengan pola pembelajaran dimana guru mentransfer pengetahuan langsung kepada peserta didik melalui ceramah tanpa memfasilitasi peserta didik untuk membangun makna melalui pembelajaran yang dilakukan.

\section{DAFTAR PUSTAKA}

Abidin,Yunus. (2014). Desain Sistem Pembelajaran : Dalam Konteks Kurikulum 2013. Bandung : Refika Aditama.

Al Muchtar, Suwarma. (2014). Inovasi dan Transformasi Pembelajaran Pendidikan IPS. Bandung : Gelar Pustaka Mandiri.

Boss, Suzie.,\& Krauss, Jane. (2007). Reinventing Project Based Learning : Your Field Guide To Real World Projects In The Digital Age. International Society for Technology In Education.

Brady, Laurie. (1985). Models and Methods Of

Teaching. Prentice-Hall Of Australia Pty.Ltd

Eggen,Paul.\&Kauchak,Don.(2012). Strategi dan Model Pembelajaran : Mengajar-kan Konten dan Ketrampilan Berpikir (edisi keenam). Jakarta : Indeks.

Maftuh, Bunyamin. \& A.K, Makah. (2007). Model Pembelajaran Pendidikan Nilai. Bandung : Maulana

Maryani, Enok. (2011). Pengembangan Program Pembelajaran IPS Untuk Peningkatan Keterampilan Sosial. Bandung : Alfabeta.

Maryani, Enok. (2008). Pengembangan Program Pembelajaran IPS Untuk Meningkatkan Kompetensi Keterampilan Sosial. [online]. Diakses dari http:/ / file.upi.edu/Direktori/FPIPS/J UR._PEND._GEOGRAFI/196001211985 032-ENOK_MARYANI/ KET_SOSIAL.

Muhaimin. (2014). Pengembangan Model Problem Based Learning Dalam Ecopedagogy Untuk Peningkatan Kompetensi Ekologis Mata Pelajaran IPS. Disertasi Prodi IPS. Sekolah Pasca Sarjana. Universitas Pendidikan Indonesia Bandung : Tidak Diterbitkan.

National Council for the Social Studies. (1994). The Curriculum Standards for Social Studies. Washington DC. : NCSS 
Palmer, Joy \& Neal, Philip. (1994). The Handbook Of Environmental Education. New York : Routledge.

Putrawan, I. Made. (2014). Konsep-konsep Dasar Ekologi Dalam Berbagai Aktivitas Lingkungan. Bandung : Alfabeta

Somantri, Muh. Numan. (2001). Menggagas Pembaharuan Pendidikan IPS. Bandung : Remaja Rosdakarya \& PPS, UPI.

Suyono \& Hariyanto. (2012). Belajar dan Pembelajaran : Teori dan Konsep Dasar. Bandung : Remaja Rosdakarya.

Uno, Hamzah. (2009). Model Pembelajaran : Menciptakan Proses Belajar Mengajar yang Kreatif dan Efektif. Jakarta : Bumi Aksara

Pooley, Ann Julie, \& O'Connor, Moira. (2000). Environmental Education And Attitudes : Emotions and Beliefs Are What Is Needed. International Journal of Environtment And Behavior, 32 (5), hlm. 711-723. [online]. Diakses dari www.eab.sagepub.com.
Suharjani, Neni. (2014). Meningkatkan Pemahaman Materi Pembangunan Berkelanjutan dalam Pendidikan IPS Melalui Pembelajaran Berbasis Masalah Sebagai Upaya Menumbuhkan Kepedulian Terhadap Lingkungan (Green Behaviour). Thesis Prodi IPS Sekolah Pasca Sarjana Universitas Pendidikan Indonesia Bandung : Tidak diterbitkan

The George Lucas Educational Foundation. (2005). Instructional Module Project Based Learning. [Online]. Diakses di http://www.edutopia.org/projectbased-learning.

Thom Markham. (2003). Handbook Project Based Learning : Second Edition. A guide to Standards Focused Project Based Learnin $g$ : For Middle and High School Teacher. [online]. Buck Institute Education. Diakses dari http://bie.org/shop/product_detail/p bl_handbook\#look_inside. 